\title{
Effect of Treatment with Conjugated Linoleic Acid on the Enzyme Carnitine Palmitoyl Transferase in Albino Mice
}

\author{
Bhyravavajhula Lalitha Devi*, Muthiah Nagasundaram², Kasturi Satyanarayana Murthy ${ }^{3}$, Chintada Ganapati Swamy ${ }^{4}$ \\ 'Bharath University, West Tambaram, Chennai, Tamil Nadu, INDIA. \\ 2Department of Pharmacology, Sri Balaji Medical College, Chennai, Tamil Nadu, INDIA \\ ${ }^{3}$ Department of Pharmacology, GSL Medical College, Rajamahendravaram, Andhra Pradesh, INDIA. \\ ${ }^{4}$ Department of Community Medicine, Department of Community Medicine, GSL Medical College, Rajamahendravaram - 533296, Andhra Pradesh, INDIA.
}

\begin{abstract}
Background: Conjugated Linoleic Acid is an omega-6 fatty acid with potential health benefits. The objective of the present study is to study the effect of Conjugated Linoleic Acid on the enzyme Carnitine Palmitoyl Transferase. Methods: Healthy Albino mice were divided into three groups viz., first group of 10 animals given high fat diet, second group of high fat diet and Conjugated Linoleic Acid treated animals and third group of control animals given normal diet. After 22 days, animals were sacrificed and hepatic and adipose tissue separated. Carnitine palmitoyl transferase estimation was done by ELISA and western blot techniques. Serum samples collected on $7^{\text {th }}, 15^{\text {th }}$ and $22^{\text {nd }}$ days and carnitine palmitoyl transferase assay done. Results: The results showed that there is an elevation of the levels of the enzyme Carnitine Palmitoyl Transferase in serum, hepatic and adipose tis-
\end{abstract}

sues as measured by both ELISA and Western blot technique. Conclusion: Conjugated Linoleic Acid, acts via elevation of the enzyme Carnitine Palmitoyl Transferase when it is given in mice and causes weight reduction.

Key words: Omega-6 fatty acid, Albino mice, Elisa, Western blot technique. Correspondence

Dr. Bhyravavajhula Lalitha Devi, 70-15-7/4, Suresh Nagar, NFCL Road, Kakinada- 533003, Andhra Pradesh, INDIA.

Phone no: +91 9949859163

Email: lalithadevid@gmail.com

DOI: 10.5530/jyp.2018.10.92

\section{INTRODUCTION}

Conjugated linoleic acid (CLA) is an omega-6 fatty acid with many health benefits and it is a mixture of different types of isomers of linoleic acid. These various isomers are derivatives of linoleic acid. CLA is mostly found in milk products and ruminant meats like beef and lamb. ${ }^{1}$ CLA is important to human health. Many animal studies have shown that CLA has got a major role in the reduction of body weight and fat deposition. Animal studies have been conducted using CLA mixtures. The mixtures contained equal amounts of trans-10, cis-12 (t10c12) and cis9, trans-11 (c9t11) isomers. In 2008, USFDA declared CLA as Generally Recognized As Safe (GRAS). Results of various studies conducted on CLA suggest that CLA alters weight gain when animals are fed with a diet which contains low or medium levels of fat. CLA has got various potent physiological functions such as anti-carcinogenic, anti-obesity, anti-diabetic and antihypertensive properties. It was found through many studies that CLA can be effective to prevent lifestyle diseases or metabolic syndrome. ${ }^{2}$ The weight lowering effect of CLA has been studied and Delany et $a^{3}$ observed that after feeding male mice with a high fat diet along with CLA, the body weight was reduced by day 22 . The same effect continued for a period of 12 weeks.

The effects of conjugated linoleic acid on body composition were further studied. Hyperlipidemia or hypercholesterolemia in rats can be induced by supplementing cholesterol diet (sub-acute model). Devi Set al, in their study tested the anti hyperchoslestrolemic potential of fresh leaves of Vitis Vinifera ${ }^{4}$ ICR mice, which were fed on a diet containing CLA, showed that body fat was reduced and lean body mass increased in a study conducted by Park Y et al. ${ }^{5}$

Carnitine palmitoyl transferase I (CPT1) also known as carnitine acyltransferase 1 (CAT1) and is responsible for the formation of acyl carnitines by catalyzing the transfer of the acyl group to l-carnitine. The product is often Palmitoyl Carnitine, but other fatty acids may also be possible. Palmitoyl Carnitine belongs to a group of other enzymes called Carnitine Acyl Transferases which causes subsequent movement of the acyl carnitine from the cytosol into the mitochondrial membrane space. CPT1 is an internal membrane protein that connects with the mitochondrial outer membrane through transmembrane regions in the peptide chain. Both the $\mathrm{N}$ - and $\mathrm{C}$ - terminals are exposed to the inner side of the membrane. Three isoforms of CPT 1 exist in the mammalian tissues. Except for skeletal muscle cells, the $1^{\text {st }}$ isoform CPT 1-A or CPT1-L is found throughout the body on the mitochondria of all cells. The second isoform CPT1B is present in brown adipose cells and heart and skeletal muscle cells. The third isoform, present in the brain, CPT $1 \mathrm{C}$, was isolated in 2002. There is not much knowledge about CPT1 C. The CPT system is vital in the beta oxidation of long chain fatty acids. This system is essential, because even though the fatty acids are activated on the outer mitochondrial membrane, the activation of fatty acids should occur within the mitochondrial matrix. Long chain fatty acids require a shuttle system to be transported into the mitochondrial inner membrane. The CPT IA form causes Carnitine Palmitoyl Transferase 1 deficiency. This rare disorder presents a risk of hepatic encephalopathy, hypoketotic hypoglycaemia, and sudden death in infancy. CPT 1 is associated with type 2 diabetes Melletus and increase of insulin resistance. CPT1 deficiency cause free fatty acid (FFA) levels in humans to become elevated, fat to accumulate in skeletal muscle, and oxidation of free fatty acids is decreased. CPT1 has been thought to be responsible for these symptoms. The decrease in CPT 1, causes a further decrease in the transport of long chain fatty acids into the mitochondria of heart and muscle, decreasing 
fatty acid oxidation in their cells. The shunting of long chain fatty acids away from mitochondria causes deposition of fat. Hence CPT1 is considered essential in the future treatment of many metabolic disorders.

\section{MATERIALS AND METHODS}

\section{Raising polyclonal antibody for human Carnitine Palmitoyl Transferase}

By using recombinant human carnitine palmitoyl transferase protein, antihuman CPT rabbit polyclonal antibody was generated. Approximately 300 micrograms of protein was emulsified with complete Freund's adjuvant (sigma) and the rabbit was immunized at multiple sites subcutaneously. Three booster doses of 150 micrograms purified protein were given with incomplete Freund's adjuvant (Sigma) at three-week intervals. After the third booster dose, the animal was bled; serum was separated and stored at $-20^{\circ} \mathrm{C}$. 1:1000 dilutions were used for western blotting and ELISA.

\section{In vivo Animal studies}

Albino mice (Musmusculus) which were healthy and ten to twelve (10-12) weeks old, thirty in number, weighing 21 to 25 gms were housed in a clean room. The mice were maintained at standard temperature of $22^{\circ} \mathrm{C}\left( \pm 3^{\circ} \mathrm{C}\right)$ with $50 \%$ to $70 \%$ relative humidity, light and dark (12h) was maintained. The feed was commercially available pellets from Hindustan lever limited, Mumbai and autoclaved Milli Q water given to the animals.

First set of 10 animals was given a high fat diet, the second set of 10 animals was given a high fat diet plus conjugated linoleic acid and third set of 10 animals were control and fed normal feed and water. A $200 \mu$ l of Blood was collected from each animal on the $7^{\text {th }}$ day, $15^{\text {th }}$ dayand on $22^{\text {nd }}$ day through retro-orbital bleeding. ${ }^{6}$ Serum was collected by centrifucation at $3000 \mathrm{RPM}$ for $20 \mathrm{~min}$. Animals were sacrificed and $500 \mathrm{mg}$ of liver and adipose tissue was rapidly excised separately. Tissues were rinsed with cold phosphate buffer and homogenized by polytron (Brinkman) in homogenization buffer (PBS containing 0.05\% sodium azide, $0.5 \%$ Triton $\mathrm{X}-100$, and a protease inhibitor cocktail, $\mathrm{pH} 7.2,4^{\circ} \mathrm{C}$ ) and then sonicated for $5 \mathrm{~min}$. Homogenates were centrifuged. Carnitine Palmitoyl Transferase amounts in the supernatants were separated and measured by means of ELISA.

\section{Carnitine Palmitoyl Transferase Assay by ELISA}

Liver and adipose tissue homogenate $(100 \mu \mathrm{l}$ per well) were placed in ELISA plate and the samples incubated at room temperature $\left(20-23^{\circ} \mathrm{C}\right)$ for $2 \mathrm{~h}$ and the ELISA plate washed 4 times with $300-350 \mu \mathrm{l} /$ well of 1x TBST (Tris Buffered Saline with 0.05\% TWEEN 20). 100 $\mu$ l/well Biotinylated anti- Carnitine Palmitoyl Transferase antibody was added and incubated for $2 \mathrm{~h}$. ELISA plate was washed 4 times with $300-350 \mathrm{ml} /$ well of 1x TBST and added $100 \mu \mathrm{l} /$ well of Streptavidin-horseradish peroxidase solution. Plates were incubated at room temperature for $30 \mathrm{~min}$. ELISA plate was washed 4 times with 300-350 $\mu \mathrm{l} /$ well of $1 \mathrm{x}$ TBST and $100 \mu \mathrm{l} /$ well of substrate solution Tetra Methyl Benzidine (TMB) added. ELISA plates were incubated at room temperature for 20-30 min. The reaction was terminated by adding $100 \mu \mathrm{l} /$ well of Stop Solution (10mM EDTA in 1XTBS). The plate was read at $450 \mathrm{~nm}$ and results were calculated.

\section{Sodium Dodecyl Sulphate Poly Acramide Gel Electrophoresis (SDS- PAGE) of proteins}

A very common method for separating proteins by electrophoresis. It uses a discontinuous polyacramide gel as a support medium and sodium dodecyl sulphate to denature the proteins. This method is called Sodium Dodecyl Sulphate Poly Acramide Gel Electrophoresis. (SDS- PAGE).

SDS-PAGE was carried out by the method described by Laemmli, 1970 in a discontinuous buffer system.

Staining of SDS-PAGE with Coomassie Brilliant Blue R 250

The gels stained with 0.5\% Coomassie Brilliant Blue R 250 in $100 \mathrm{ml}$ of methanol : acetic acid : water $(45: 10: 45)$ for $2-3 \mathrm{~h}$ and destained in $200 \mathrm{ml}$ of methanol : acetic acid : water $(45: 10: 45)$ for $3-4$ hrs on a shaker, with several changes of the destaining solution. Then the proteins were transferred from SDS-PAGE to PVDF membrane.

\section{Western blot analysis of proteins Immunodetection by colour reaction (ALP)}

The blot was thoroughly washed in PBS- phosphate buffer solution to remove Ponceau and blocked with 5\% Blotto in TBST (Tris Buffered Saline containing $0.1 \%$ Tween 20 ) for one hour at room temperature. The blot was rinsed with TBST and incubated with the primary antibody and rabbit CLP antibody (1:1000 dilution) diluted appropriately in TBST for 1-2 hrs at room temperature, washed 3 times for 5-10 min each with TBST, followed by incubation with alkaline phosphataseconjugated antibody diluted in TBST for $45 \mathrm{~min}$ at room temperature. The blot was then washed 3 times for 5-10 min each with TBST. The blot was developed in $100 \mathrm{mM}$ tris. $\mathrm{HCl} \mathrm{pH} 9.0,10 \mathrm{mM} \mathrm{MgCl} 2,100 \mathrm{mM}$ $\mathrm{NaCl}$, with $100 \mathrm{mg} / \mathrm{ml} \mathrm{NBT}$ and $50 \mathrm{mg} / \mathrm{ml} \mathrm{BCIP}$ as substrate for alkaline phosphatase- conjugated secondary antibodies.

\section{RESULTS}

Statistical analysis was performed by using SPSS software version 20.0 and MS Excel 2007. Descriptive statistical data was presented as mean + standard deviation and percentages. Independent student- $t$ test was performed to compare the means of two different groups of continuous variables. Anova was used to compare the mean of different continuous groups. For statistical analysis $P<0.05$ was considered as statistically significant.

According to the results, it was noted that Carnitine palmitoyl transferase enzyme was elevated on the day 22 when serum was tested and the p value came as significant. When the animals were sacrificed and the hepatic tissue tested on $22^{\text {nd }}$ day the $\mathrm{p}$ value is again significant. Similarly, when the adipose tissue was tested on day $22^{\text {nd }}$ the $p$ value came significant. To compare between the groups, Student- $t$ test was employed and One Way Anova was used to compare within the groups.

Group A is the test group

Group B is the control group for all the tests.

When Student- $t$ test was employed to compare between the groups on the $7^{\text {th }}$ day the p-value was 0.85 and is not significant and on $15^{\text {th }}$ and $22^{\text {nd }}$ day the p-value is 0.00 , which is highly significant.

When the hepatic and adipose tissue values on $22^{\text {nd }}$ day were analysed, it was observed that $\mathrm{p}$ value is 0.00 and came as significant.

When Anova was employed to compare within the group for $7^{\text {th }}, 15^{\text {th }}$ and 22 nd days, the p value 0.00 and came as highly significant.

\section{DISCUSSION}

The present study is conducted to see the effect of Conjugated Linoleic Acid, the test drug on the enzyme Carnitine Palmitoyl Transferase which is involved in the fatty acid oxidation thereby causing lipolysis. The study was conducted for a period of 22 days and in one group of 10 animals, high fat diet was given as $5 \mathrm{mg}$ per $\mathrm{kg}$ body weight. In the second group of 10 animals, high fat diet was given and also conjugated linoleic acid 


\begin{tabular}{|c|c|c|c|c|}
\hline \multicolumn{5}{|c|}{$t$ Test } \\
\hline & & Mean & Std. Deviation & p-value \\
\hline \multirow{2}{*}{ Average OD $7^{\text {th }}$ day } & A & 0.64 & 0.01 & \multirow{2}{*}{0.85} \\
\hline & B & 0.64 & 0.02 & \\
\hline \multirow{2}{*}{ Average OD $15^{\text {th }}$ day } & A & 0.61 & 0.01 & \multirow{2}{*}{0.00} \\
\hline & B & 0.57 & 0.01 & \\
\hline \multirow{2}{*}{ Average OD $22^{\text {nd }}$ day } & A & 0.73 & 0.01 & \multirow{2}{*}{0.00} \\
\hline & B & 0.58 & 0.00 & \\
\hline
\end{tabular}

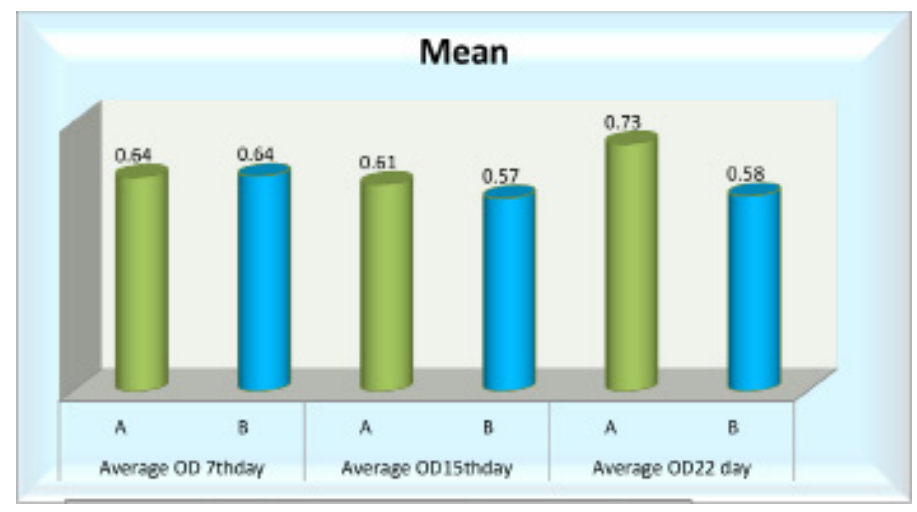

\begin{tabular}{ccccc}
\hline \multicolumn{5}{c}{ Group Statistics } \\
\hline & & Mean & Std. Deviation & p-value \\
\hline \multirow{2}{*}{ hepatic tissue 22 d } & A & 0.75 & 0.01 & 0.00 \\
Adipose tissue 22d & B & 0.57 & 0.01 & \\
& A & 0.73 & 0.01 & 0.00 \\
& B & 0.58 & 0.00 & \\
\hline
\end{tabular}

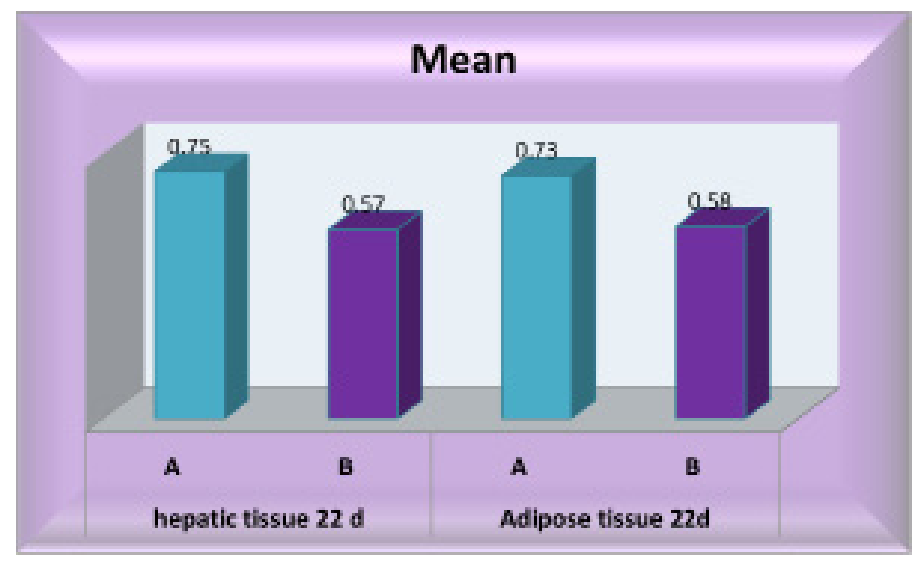

\begin{tabular}{|c|c|c|c|c|}
\hline \multicolumn{5}{|c|}{ ANOVA WITHIN GROUP } \\
\hline & & \multirow[t]{2}{*}{ Mean } & \multirow{2}{*}{$\begin{array}{l}\text { Std. Deviation } \\
\text { Lower Bound }\end{array}$} & $\begin{array}{l}95 \% \text { Confidence } \\
\text { Interval for Mean }\end{array}$ \\
\hline & & & & Upper Bound \\
\hline \multirow{3}{*}{$\begin{array}{l}\text { average OD } \\
\text { within group }\end{array}$} & 7.00 & 0.64 & 0.01 & 0.62 \\
\hline & 15.00 & 0.61 & 0.01 & 0.60 \\
\hline & 22.00 & 0.73 & 0.01 & 0.72 \\
\hline
\end{tabular}

in the same dose of $5 \mathrm{mg} / \mathrm{kg}$. Third group of 10 animals kept as control. The CPT assay was done on $7^{\text {th }}, 15^{\text {th }}$ and $22^{\text {nd }}$ day in serum. On the $22^{\text {nd }}$ day CPT assay was also done in adipose and hepatic tissue also. From the tests, it was evident that there is a rise in the enzyme CPT more on $15^{\text {th }}$ and $22^{\text {nd }}$ day in the serum, on the 22 nd day, there is elevation of CPT in the adipose and hepatic tissue also.

In 1987, Ha YL et al initially discovered CLA and identified anticarcinogenic property. ${ }^{7}$ Subsequently, CLA was shown to exhibit anti-obesity properties also. Due to the increase in the prevalence of obesity over the past 30 years, the utility of CLA as weight loss medication is also on an increase. Treatment with CLA mainly t10c12 isomer, decreases body fat mass in many studies. Of the two major isomers of CLA, t10 c12 isomer has been proved to have the main anti-obesity effect. Park et al first demonstrated that CLA modulated body composition. In this study, both male and female mice had less BFM (Body Fat Mass) when compared to controls. Subsequently, it was demonstrated through other studies that CLA supplementation reduces body fat mass in mice and rats. But the results are less consistent in humans. Other studies show that CLA decreases BFM at the same time increasing lean body mass (LBM). Supplementation of a CLA mixture in overweight and obese people (3-4 g/day for 24 weeks) decreased BFM and increased lean body mass (LBM). ${ }^{8}$

It was postulated that CLA increases resting metabolism, which is a function of basal metabolic rate (BMR), thermogenesis, and physical exercise. CLA has been proposed to reduce body fat by elevating energy expenditure via increased BMR, thermogenesis, or lipid oxidation in animals. Studies showed that CLA supplementation increased lean body mass by increasing energy consumption. For example, CLA supplementation ( $6.4 \mathrm{~g} /$ day for 12 weeks) increased LBM by a minimum of $0.64 \mathrm{~kg}$ in healthy obese humans when compared to controls. ${ }^{9}$

Supplementation with $\mathrm{t} 10, \mathrm{c} 12$ CLA in rodents has been shown to induce uncoupling protein 2 transcription in white adipose tissue (WAT).$^{10}$ CLA also caused increased expression of Carnitine Palmitoyl Transferase1 (CPT1) in white adipose tissue (WAT) of mice, which are treated with $\mathrm{t} 10 \mathrm{c} 12 \mathrm{CLA} \cdot{ }^{11,12} \mathrm{CPT} 1$ is involved in fatty acid uptake by mitochondria and is responsible for the rate-limiting step of fatty acid oxidation as already discussed before.

It is supposed that CLA may increase PPAR $\gamma$ activity due to its proinflammatory effects in adipocytes thereby reducing lipid formation. According to previous studies, treatment with 10,12 CLA has been shown to increase the secretion of interleukins 6 and 8 from rodents ${ }^{13}$ and human ${ }^{14}$ adipocyte cultures, and TNF- $\alpha$ thereby suppressing insulin sensitivity ${ }^{15,16}$

The potential mechanism responsible for anti-obesity effect of CLA is the ability of CLA to increase fatty acid oxidation in the liver and adipose tissues. Many studies have confirmed the ability of CLA to increase fatty acid oxidation. In a similar study conducted by Sharma $\mathrm{G}$ et al, Pre-adipocyte differentiation assay (3T3-L1) was used for studying antiadipogenic activity of the extract of Prunus Persica. ${ }^{17}$ According to the study conducted by Martin et al, they concluded that hepatic and adipose Carnitine Palmitoyl Transferase (CPT) activity, was increased in rats when they are fed a diet containing t10c12 CLA for 6 weeks. CPT is a rate-limiting enzyme for fatty acid oxidation. Moreover, rats fed with mixed CLA isomers produced lower respiratory quotients, which indicates increased oxidation in the body. These results, together with other studies, suggest that CLA has got the ability to increase fat oxidation. ${ }^{18,19}$

In a study conducted by Rahmani A. H. et al, they observed that the extract of Pomegranate (Punica granulatum) has got potential for health management ${ }^{20}$ in a similar way to CLA. Similarly, Iram Nazis et al conducted a study on the anti-obesity effect of Zingiber officinale (Ginger) ${ }^{21}$ Finally from the present study conducted and many previous studies in animals 
and some studies in humans we can conclude that CLA acts by elevating the enzyme Carnitine Palmitoyl Transferase which acts by means of increasing fatty acid oxidation and causing lipolysis and reduction of weight.

\section{CONCLUSION}

From this study, it is observed that there is an elevation of the enzyme Carnitine Palmitoyl Transferase when Conjugated linoleic acid, the test drug is given in albino mice. Finally, it is inferred that CLA acts by elevating the enzyme CPT which acts by causing fatty acid beta-oxidation and thereby lipolysis and weight reduction. In the present scenario, CLA could be recommended as a healthy food supplement for weight reduction in the place of conventional medicines to reduce the adverse effects. However, more studies on animal models with CLA should be conducted to explore further health benefits.

\section{ACKNOWLEDGEMENT}

The authors express their sincere thanks to Dr. Moses and Dr. Subrahmanian of Rx Biosciences Laboratory, Hyderabad for contributing to the work of the enzyme assay of CPT.

\section{CONFLICT OF INTEREST}

The authors declare no conflict of interest.

\section{ABBREVIATIONS}

CLA: Conjugated Linoleic Acid; CPT: Carnitine Palmitoyl Transferase; CPT1: Carnitine Palmitoyl Transferase 1; CA 1: Carnitine Acyl Transferase 1; TBST: Tris Buffered Saline with Tween 20; SDS: PAGE-Sodium Dodecyl Sulphate Poly Acramide Gel Electrophoresis of proteins; PBS: Phosphate Buffer Solution; BFM: Body Fat Mass; LBM: Lean Body Mass; BMR: Basal Metabolic Rate; WAT: White Adipose Tissue.

\section{REFERENCES}

1. Lin H, BoylstonTd, Chang Mj, Luedecke LO, Schultz TD. Survey of the conjugated linoleic acid contents in dairy products. J Dairy Sc. 1995;78(11):2358-65.

2. Kazunori K, Teruyoshi Y. Health benefits of conjugated linoleic acid (CLA). Obes Res Clin Pract. 2014;8:525-32.

3. DeLany JP, Blohm F, Truett AA, Scimeca JA, West DB. Conjugated linoleic acid rapidly reduces body fat content in mice without affecting energy intake. Am J Physiol. 1999;276(4):1172-9.

4. Devi S, Singh R. Anti-oxidant and Anti-hypercholesterolemic potential of Vitis Vinifera leaves. Pharmacog. J. 2017;9(6):807-14
5. Park Y, Albright KJ, Lin w, Storkson JM, Cook ME, Pariza MW. Effect of conjugated linoleic acid on body composition in mice. J Lipids Res. 1997;32(8):853-8.

6. Parasuraman S, Zhen KM, Raveendran R. Retro-orbital sample collection in Rats - a video article. PTB Reports. 2015;1(2):37-40.

7. Ha YL, Grimm NK, Pariza MW. Anticarcinogens from fried ground beef: heataltered derivatives oflinoleic acid. Carcinogenesis. 1987;8(12):1881-7.

8. Gaullier JM, Halse J, Høivik HO, Høye K, Syvertsen C, Nurminiemi M et al. Six months supplementation with conjugated linoleic acidinducesregional-specificfat mass decreases in overweight and obese. Br J Nutr. 2007;97(3):550-60.

9. Steck SE, Chalecki AM, Miller P, Conway J, Austin GL, Hardin JW et al. Conjugated linoleic acid supplementation for twelve weeks increases lean body mass in obese humans. J Nutr. 2007;137(5):1188-93.

10. House RL, Cassady JP, Eisen EJ, Eling TE, Collins JB, Grissom S et al. Functional genomic characterization of delipidation elicited by trans-10, cis-12-conjugated linoleic acid (t10c12-CLA)in a polygenic obese line of mice. Physiol Genomics. 2005;21(3):351-61.

11. LaRosa PC, Miner J, Xia Y, Zhou Y, Kachman S, Fromm ME. Trans-10, cis-12 conjugated linoleic acid causes inflammation and delipidation of white adipose tissue in mice: a microarray andhistological analysis. Physiol Genomics. 2006;27(3):282-94.

12. Martin JC, Grégoire S, Siess MH, Genty M, Chardigny JM, Berdeaux O et al. Effects of conjugated linoleic acid isomers on lipid-metabolizing enzymes in male rats. J Lipids Res. 2000;35(1):91-8.

13. Poirier H, Shapiro JS, Kim RJ, Lazar MA. Nutritional supplementation with trans-10, cis-12conjugated linoleic acid induces inflammation of white adipose tissue. Diabetes. 2006;55(6):1634-40.

14. Brown J, Boysen M, Chung S, Fabiyi O, Morrision R, Mandrup S et al. Conjugated linoleic acid (CLA) induces human adipocyte delipidation: autocrine/ paracrine regulation of MEK/ERKsignaling by adipocytokines. J Biol Chem. 2004;279(25):26735-47.

15. Purushotham A, Wendel AA, Liu L, Belury MA. Maintenance of adiponectin attenuates insulin resistance induced by dietary conjugated linoleic acid in mice. J Lipid Res. 2007;48(2):444-52.

16. Liu LF, Purushotham A, Wendel AA, Belury MA. Combined effects of rosiglitazone andconjugatedlinoleicacid on adiposity, insulin sensitivity, and hepatic steatosis in high-fat-fed mice. Am J Physiol. 2007;292(6):1671-82.

17. Sharma G, Kumar S, Sharma M, Upadhyay N, Kumar S, Ahmed Z et al. Anti-Diabetic, Anti-Oxidant, and Anti-Adipogenic potential of Quercetin Rich Ethyl AcetateFractionOf Prunus persica. Pharmacog J. 2018;10(3):463-69.

18. Azain MJ, Houseman DB, Sisk MB, Flatt WP, Jewell DE. Dietary conjugated linoleic acid reduced rat adipose tissue cell size rather than cell number. J Nutr 2000;130(6):1548-54

19. Ohnuki K, Haramizu S, Oki K, Ishihara K, Fushiki. A single oral administration of conjugated linoleic acid enhanced energy metabolism in mice. J Lipids Res. $2001 ; 36(6): 583-87$.

20. Rahmani A H, Alsahi M A, Almatroodi S A. Active constituents of Pomegranate (Punica granatum) as potential candidates in the management of health through modulation of biological activities, Pharmacog J. 2017;9(5):689-95.

21. Iram N, Ansari SH, Poonam A, Adil A. Anti-obesity activity of Zingiber Officinale. Pharmacog J. 2016:8(5):440-46.

Article History: Submission Date : 18-05-2018; Revised Date : 16-07-2018; Acceptance Date : 15-08-2018.

Cite this article: Devi BL, Muthiah NS, Murthy KS, Swamy G. Effect of Treatment with Conjugated Linoleic Acid on the Enzyme Carnitine Palmitoyl Transferase in Albino Mice. J Young Pharm. 2018;10(4):418-21. 